\title{
ASO Author Reflections: Time for a Paradigm Shift in "Hormone Receptor Positive" Invasive Breast Cancer?
}

\author{
Christine Dauphine, MD \\ Division of Surgical Oncology, Department of Surgery, Harbor-UCLA Medical Center, Torrance, CA
}

The Current National Comprehensive Cancer Network ${ }^{1}$ and American Society of Clinical Oncology ${ }^{2}$ clinical practice guidelines outline treatment algorithms for "hormone receptor positive" human epidermal growth factor receptor 2 (HER2)-negative invasive breast cancers, not specifically accounting for the estrogen receptor (ER) and progesterone receptor (PR) status individually. This is largely due to the fact that clinical trials have routinely grouped cancers as "hormone receptor positive" regardless of whether one or both ER and PR stain positive in at least $1 \%$ of cells on immunohistochemical evaluation of tissue samples.

In our study ${ }^{3}$ of the National Cancer Database, singlehormone receptor positive cancers $(\mathrm{ER}+\mathrm{PR}-$ and $\mathrm{ER}-\mathrm{PR}+$ ) were significantly more likely than $\mathrm{ER}+\mathrm{PR}+$ cancers to exhibit unfavorable tumor characteristics: higher grade, lymphovascular invasion, tumor size greater than 2 $\mathrm{cm}$, node positivity, stage IV disease at presentation, and a higher multigene assay score. These single hormone receptor-positive phenotypes also had poorer overall survival than $\mathrm{ER}+\mathrm{PR}+$ cancers, with the outcomes of $\mathrm{ER}-\mathrm{PR}+$ cancers similar to $\mathrm{ER}-\mathrm{PR}-$ across all stages of disease.

The implication of these findings is that future clinical trials and treatment guidelines should consider both $\mathrm{ER}+\mathrm{PR}-$ and $\mathrm{ER}-\mathrm{PR}+$ invasive breast cancers distinct from $\mathrm{ER}+\mathrm{PR}+$ cancers. It is increasingly apparent that PRnegative status is a key determinant in distinguishing

(C) Society of Surgical Oncology 2020

First Received: 12 July 2020

Accepted: 14 July 2020;

Published Online: 28 July 2020

C. Dauphine, MD

e-mail: cdauphine@dhs.lacounty.gov luminal A from luminal B phenotypes. ${ }^{4}$ Additionally, $\mathrm{ER}-\mathrm{PR}+$ cancers do not appear to exhibit any benefit in outcome over ER-PR - (triple negative) cancers. As such, it is imperative to account for the differences in prognosis and survival associated with single versus dual hormone receptor-positive cancers. Our data suggest that a paradigm shift in the definition of "hormone receptor positive" breast cancer is needed in future clinical trials and subsequent treatment guidelines to account for single hormone receptor-positive disease separately from $\mathrm{ER}+\mathrm{PR}+$ phenotypes.

FUNDING This study did not receive funding support.

DISCLOSURE None.

\section{REFERENCES}

1. National Comprehensive Cancer Network Breast Cancer (Version 3.2020). Invasive Breast Cancer, Systemic Adjuvant Treatment (BINV-4). https://www.nccn.org/professionals/physician_gls/pdf/b reast.pdf. Accessed July 7, 2020.

2. American Society of Clinical Oncology Practice Guidelines. Role of patient and disease factors in adjuvant systemic therapy decision-making for early-stage, operable breast cancer. https:// www.asco.org/research-guidelines/quality-guidelines/guidelines/b reast-cancer\#/10696. Accessed July 7, 2020.

3. Dauphine C, Moazzez A, Neal J, Chlebowski R, Ozao-Choy J. Single hormone receptor positive breast cancers have distinct characteristics and survival. Ann Surg Oncol. 2020. https://doi.org/ 10.1245/s10434-020-08898-5.

4. Prat A, Cheang MC, Martin M, et al. Prognostic significance of progesterone receptor-positive tumor cells within immunohistochemically defined luminal A breast cancer. J Clin Oncol. 2013;31(2):203-9.

Publisher's Note Springer Nature remains neutral with regard to jurisdictional claims in published maps and institutional affiliations. 